\title{
ANALISIS KUALITAS TIDUR BAYI YANG DILAKUKAN PEMIJATAN DI RIU MOM \& BABY SPA SUKOHARJOPATI
}

\author{
Sifa Altika ${ }^{1}$, Siti Ni'amah'2). \\ ${ }^{1}$ Kebidanan, STIKes Bakti Utama Pati (penulis 1) \\ ${ }^{2}$ Kebidanan, STIKes Bakti Utama Pati (penulis 2) \\ Email: (sifa.altika@gmail.com)
}

\begin{abstract}
ABSTRAK
Kualitas tidur bayi dikatakan kurang jika bayi mengalami gangguan tidur jika pada malam hari tidurnya kurang dari 9 jam, terbangun lebih dari 3 kali dan lama terbangunnya lebih dari 1 jam. Selama tidur bayi terlihat selalu rewel, menangis dan sulit tidur kembali. Pijat bayi menyatakan bahwa bayi akan lebih merasa nyaman, tidak mudah rewel dan akan mudah tidur serta nafsu makan bertambah. Tujuan penelitian ini untuk menganalisis pijat bayi dengan kualitus tidur. Jenis penelitian yang digunakan adalah survey analitik dengan sampel sebanyak 30 responden. Teknik sampling menggunakan total sampling. Hasil penelitian menunjukkan bahwa Kualitas Tidur Pada Bayi yang melakukan pijat baik 18 orang $(60,0 \%)$, kualitas tidur cukup 9 orang $(30,0 \%)$, sedangkan kualitas tidur kurang 3 orang $(10,0 \%)$. Pijat bayi dapat mempengaruhi keluarnya hormone tidur (melatonin), dimana dengan hormone tersebut bayi dapat memiliki pola tidur yang teratur. Berdasarkan hasil dan kesimpulan penelitian terkait kualitas tidur bayi, sehingga dapat disarankan perlu adanya penyebaran/ infomasi kepada ibu terkait dengan pijat bayi, serta ibu bayi dapat melakukan dan menerapkan teknik pijat bayi secara mandiri dan untuk selanjutnya dapat dilakukan pengembangan penelitian terkait analisis status melatonin pada bayi yang melakukan pemijatan.
\end{abstract}

Kata Kunci: Pijat, Bayi, Kualitas tidur

\begin{abstract}
Quality of sleeping babies is said to be lacking if the baby has sleep disorder if at night he sleeps less than 9 hours, wakes up more than 3 times and wakes up more than 1 hour. During babies sleep the baby looks always fussy, crying and difficulty falling sleeping again. Baby massage states that the baby will feel more comfortable, not easily fussy and will easily sleep and increase appetite. The purpose of this study was to analyze baby massage with sleep quality. This type of re search is an analytic survey with a sample of 30 respondents. The sampling technique uses total sampling. The results showed that sleep quality who had a good baby massage 18 people $(60.0 \%)$, enough sleep quality 9 people (30.0\%), while sleep quality lacked 3 people (10.0\%). Baby massage can affect the release of the sleep hormone (melatonin), where with the hormone the baby can have re gular sleep patterns. Based on the results and conclusions of research related to the sleep quality of baby massage, so it can be suggested the need fordissemination / information to mothers related to baby massage, and the baby's mother can do and apply baby massage techniques independently and to further develop research related to the analysis of melatonin status in baby who do massage.
\end{abstract}

Keywords: massage, baby, quality of sleeping

\section{PENDAHULUAN}

Pertumbuhan dan perkembangannya sangat tergantung dari tidur, tanpa tidur bayi tidak akan tumbuh secara optimal, karena pada saat inilah terjadi perbaikan sel-sel otak dan kurang lebih $75 \%$ hormon pertumbuhan diproduksi. Telah dibuktikan tidur mempunyai efek yang besar terhadap kesehatan mental, emosi dan fisik, dan sistem imunitas tubuh. Adanya abnormalitas pada otak juga dapat diketahui dari bagaimana pola tidur anak tersebut. Dan gangguan tidur akan mengakibatkan efek yang sebaliknya (Sudarti, 2015)

Menurut Wahyuni (2008), kualitas 
tidur bayi dikatakan baik jika bayi tidak mengalami gangguan tidur seperti yang tidur cukup tanpa sering terbangun dan akan lebih bugar dan tidak gampang rewel. Kualitas tidur bayi dikatakan kurang jika bayi mengalami gangguan tidur jika pada malam hari tidurnya kurang dari 9 jam, terbangun lebih dari 3 kali dan lama terbangunnya lebih dari 1 jam.Selama tidur bayi terlihat selalu rewel, menangis dan sulit tidur kembali (Wahyuni, 2008) dalam Riadian (2016).

Salah satu upaya untuk meningkatkan kualitas tidur adalah dengan pemberian pijat atau terapi sentuh. Peneliti dari Warwick Medical School dan Institute of Education dari University of Warwick, meneliti 9 macam gerakan pijat bayi yang diterapkan kepada 598 bayi usia di bawah 6 bulan. Hasil penelitian tersebut salah satunya disebutkan bahwa pijat bayi dapat mempengaruhi keluarnya hormon tidur melatonin, dengan hormon tersebut bayi dapat memiliki pola tidur yang teratur (Roesli, 2010).

Sekitar 50\% anak pada usia 6-12 bulan akan mengalami gangguan tidur dimalam hari,anak akan terbangun pada malam hari sering terjadi pada anak yang telalu lama tidur disiang hari atau pada anak yang terlalu semangat untuk bermain sebelum tidur (Rochtiningsing, 2010).

Di Indonesia cukup banyak bayi yang mengalami masalah tidur, yaitu sekitar $44,2 \%$ bayi mengalami gangguan tidur seperti sering terbangun di malam hari. Namun lebih dari $72 \%$ orang tua menganggap gangguan tidur pada bayi bukan suatu masalah atau hanya masalah kecil, hal tersebut diungkapkan oleh sebuah penelitian pada tahun 2004-2005 yang dilaksanakan di lima kota besar di Indonesia (Jakarta, Bandung, Medan, Palembang dan Batam).

Penelitian ini bertujuan untuk Mengetahui kualitas tidur pada bayi yang melakukan pemijatan Kecamatan Sayung Kab. Demak.

\section{METODE}

Desain penelitian yang digunakan adalah studi analitik. Populasi penelitian ini adalah seluruh ibu yang mempunyai bayi usia 6-12 bulan dan datang di RIU mom \& baby SPA untuk memijatkan bayinya, dengan kriteria bayi pernah dipijit minimal 2 kali. Sampel yang digunakan 30 responden. Teknik pengambilan sampel menggunakan Accidental Sampling yang secara kebetulan bertemu dengan peneliti dapat digunakan sebagai sampel, bila dipandang orang yang kebetulan ditemui memenuhi kriteria pemilihan sampel, sampai jumlah sampel yang diperlukan terpenuhi. Waktu penelitian pada bulan Juni 2019. Pengumpulkan data pada penelitian ini adalah menggunakan kuesioner dan hasil perolehan data dilakukan analisis data berdasarkan distribusi frekuensi yang kemudian disajikan dalam bentuk deskriptif.

\section{HASIL}

Hasil penelitian ini disajikan dalam tablem distribusi flekuensi dijelaskan sebagai berikut:

Tabel 1.

Distribusi fre kuensi jenis kelamin

\begin{tabular}{lcc}
\hline Jenis Kelamin & Frekuensi & Prosentase \\
\hline Laki-laki & 14 & $46,6 \%$ \\
\hline Perempuan & 16 & $53,4 \%$ \\
\hline Total & $\mathbf{3 0}$ & $\mathbf{1 0 0 \%}$ \\
\hline Berdasarkan tabel 1. Menyakan hasil & $\begin{array}{l}\text { perempuan lebih banyak yaitu 16 bayi (53,3 } \\
\%) \text { dan jumlah bayi laki-laki sebanyak 14 } \\
\text { istribusi frekuensi jenis kelamin bayi yang }\end{array}$
\end{tabular}

SPA menyatakan bahwa jumlah bayi 
Tabel 2.

Distribusi fre kuensi usia bayi

\begin{tabular}{lcl}
\hline Usia Bayi & Fre kuensi & Prosentase \\
\hline 1 bulan & 3 & $10 \%$ \\
\hline 2 bulan & 5 & $16,7 \%$ \\
\hline 3 bulan & 8 & $26,7 \%$ \\
\hline 4 bulan & 6 & $20 \%$ \\
\hline 5 bulan & 4 & $13,3 \%$ \\
\hline 6 bulan & 4 & $13,3 \%$ \\
\hline Total & $\mathbf{3 0}$ & $\mathbf{1 0 0 \%}$
\end{tabular}

Berdasarkan tabel 2. Menyatakan bahwa distribusi frekuensi usia bayi tertinggi pada usia 3 bulan sebanyak 8 bayi (26,7\%), di ikuti dengan bayi usia 4 bulan sebanyak 6 bayi (20\%), usia 2 bulan sebanyak 5 bayi (16,7 $\%$ ), usia 5 dan 6 bulan yang masing-masing 4 bayi $(13,3 \%)$ dan paling rendah adalah bayi usia 1 bulan sebanyak 3 bayi (10\%).

Tabel 3.

Distribusi frekuensi pola nutrisi bayi

\begin{tabular}{lcl}
\hline \multicolumn{1}{c}{ Pola Nutrisi } & Frekuensi & Prosentase \\
\hline ASI Ekslusif & 8 & $26,7 \%$ \\
\hline ASI-Sufor & 10 & $33,3 \%$ \\
\hline Sufor & 7 & $23,3 \%$ \\
\hline Sufor-MPASI & 5 & $16.7 \%$ \\
\hline Total & $\mathbf{3 0}$ & $\mathbf{1 0 0 \%}$ \\
\hline
\end{tabular}

Berdasarkan tabel 3. Menggambarkan bahwa sebagian besar bayi yang datang untuk melakukan pijit bayi menggunakan atau mengkonsumsi ASI dan susu formula sebanyak 10 bayi (33,3\%), yang ASI ekslusif 8 bayi $(26,7 \%)$, mengkonsumsi susu formula aja sebanyak 7 bayi $(23,3 \%)$ dan diakhiri dengan konsumsi sufor serta mendapatkan MPASI sebanyak 5 bayi $(16,7 \%)$ 
Tabel 4.

Distribusi fre kuensi kualitas tidur bayi

\begin{tabular}{lcc}
\hline Kualitas Tidur & Frekuensi & Prosentase \\
\hline Baik & 18 & 60.0 \\
\hline Cukup & 9 & 30.0 \\
\hline \multirow{2}{*}{ Kurang } & 3 & 10.0 \\
\hline Total & $\mathbf{3 0}$ & $\mathbf{1 0 0 \%}$ \\
\hline
\end{tabular}

Berdasarkan tabel 4. Menjelaskan distribusi frekuensi kualitas tidur bayi yang mendapatkan /melakukan pemijatan dengan hasil terbanyak dengan kualitas tidur baik sebanyak 18 bayi (60\%), kuliatas tidur cukup 9 bayi (30\%) dan kualitas tidur kurang sebanyak 3 bayi (10\%)

\section{PEMBAHASAN}

Kualitas tidur bayi adalah keadaan mutu fisiologis tubuh yang diperoleh selama seseorang tidur, yang berfungsi sebagai proses pemulihan tubuh yang terjadi pada seseorang ketika bangyn. Kualitas tidur baik jika secara fisiologis tubuh dalam hal ini otak serta pertumbuhan dan berkembangan tubuh menjadi lebih bagus saat bangun tdur.

Pada penelitian ini kualitas tidur bayi yang mendapatkan pemijatan baik 18 orang $(60,0 \%)$ setelah melakukan pemijatan karena responden menyatakan bahwa bayi akan tidur tenang setelah dilakukan pemijatan

Kualitas tidur bayi dikatakan baik jika bayi tidak mengalami gangguan tidur seperti yang tidur cukup tanpa sering terbangun dan akan lebih bugar dan tidak gampang rewel. Kualitas tidur bayi dikatakan kurang jika bayi mengalami gangguan tidur yaitu pada malam hari tidurnya kurang dari 9 jam, terbangun lebih dari 3 kali dan lama terbangunnya lebih dari 1 jam. Selama tidur bayi terlihat selalu rewel, menangis dan sulit tidur kembali (Riadian, 2010).

Bayi setelah dilakukan pemijatan menunjukkan peningkatan kualitas tidur yang baik karena pijat dapat mempunyai efek positif pada kesehatan bayi, sehingga bayi tidur cukup tanpa sering terbangun dan tidak mudah rewel, hal ini sejalan dengan penelitian yang dilakukan oleh Siti Rohmah (2016). Setelah mendapat perlakuan pemijatan. Pijatan dapat mengubah gelombang otak, pijat bayi akan membuat bayi tidur lebih lelap dan meningkatkan kesiagaan (allertness) atau konsentrasi karena dapat mengubah gelombang otak dengan cara menurunkan gelombang beta serta tetha (Dwi, U.dkk., 2014)

Pijat bayi dapat mempengaruhi keluarnya hormone tidur (melatonin), dimana dengan hormone tersebut bayi dapat memiliki pola tidur yang teratur. Melatonin merupakan hormone utama yang dihasilkan oleh kelenjar pineal. Sekresinya distimulasi oleh gelap dan dihambat oleh cahaya, melatonin ini meningkat pada malam hari, produksi melatonin meningkat bila reseptor sel tubuh manusia menangkap pesan bahwa intensitas cahaya mulai berkurang. Manfaat lain melatonin adalah sebagai antioksidan yang larut dalam lemak dan air, meningkatkan imun tubuh, menimbulkan relaksasi otot dan menghilangkan ketegangan.

Kualitas tidur bayi berkaitan erat dengan lama tidur bayi yang lebih lama. Lama tidur yang lebih banyak ini dikarenakan bahwa pada saat bayi dipijat maka tubuh bayi akan melepaskan oksitosin dan endorfin. Endorfin merupakan hormon pereda nyeri sehingga mengusir rasa tidak nyaman dan meningkatkan kualitas tidur. (Handayani, et al., 2012).

kualitas tidur yang meningkat ditunjukkan dengan meningkatnya kuantitas tidur pada bayi menjadi lebih tinggi. Pelepasan oksitosin dan endorphin juga diketahui bahwa pada pemijatan terutama daerah perut juga dapat menstimulasi dan membantu system pencernaan. Pemijatan ini dapat dirangsang saraf vegus yang berfungsi meningkatkan daya peristaltic kontraksi berirama yang menggerakkan makanan melewati saluran pencernaan. Dengan adanya pencernaan yang baik maka bayi akan merasakan nyaman dan dapat tertidur lebih pulas.

Aktifitas pemijatan dapat meningkatkan aktifitas neurotransmitter serotonin, yaitu meningkatkan kapasitas sel reseptor yang berfungsi meningkat . glucocorticoid (adrenalin, suatu hormon stres). 
Proses ini akan menyebabkan terjadinya penurunan kadar hormon adrenalin, penurunan kadar hormon ini akan meningkatkan daya tahan tubuh terutama Immunoglobulin $\mathrm{M}$ (IgM) dan Immunoglobulin G (IgG). Sehingga pada bayi yang mendapatkan pemijatan akan mempunyai daya tahan tubuh yang lebih baik. (Syaukani, 2015) Hal ini menjadikan bayi lebih sehat dan tidak mudah sakit. Pada bayi yang sehat akan mempunyai pola tidur yang normal. Menurut Irmawati (2015), pada saat proses pemijatan pada bayi akan membuat bayi merasa lebih tenang. Pijatan yang lembut pada kulit bayi akan menenangkan bayi. Hal ini juga diperkuat oleh Handayani, et al., 2012), bahwa pijat bayi akan membangun bounding lewat kontak mata, kulit, aroma tubuh dan suara sehingga akan memberikan manfaat yang optimal bagi khususnya bagi kuantitas dan kualitas tidur pada bayi (Warsini, Nugraini, 2016)

\section{SIMPULAN DAN SARAN Simpulan}

Berdasarkan hasil analisis dan pembahasan yang dilakukan oleh peneliti maka dapat disimpulkan bahwa kualitas tidur bayi yang dilakukan pemijatan baik sebanyak $60 \%$.

\section{Saran}

Berdasarkan hasil dan kesimpulan penelitian terkait kualitas tidur bayi, sehingga dapat disarankan perlu adanya penyebaran/ infomasi kepada ibu terkait dengan pijat bayi, serta ibu bayi dapat melakukan dan menerapkan teknik pijat bayi secara mandiri dan untuk selanjutnya dapat dilakukan pengembangan penelitian terkait analisis status melatonin pada bayi yang melakukan pemijatan.

\section{DAFTAR PUSTAKA}

1. Dewi, U., Aminin, F. and Gunnara, H., 2014. Pengaruh Pemijatan terhadap Kualitas Tidur Bayi Usia 3-4 Bulan di Posyandu Gelatik dan Nuri Kelurahan Tanjungunggat Wilayah Kerja Puskesmas Sei Jang Kota Tanjungpinang Tahun 2014. Jurnal Ners dan Kebidanan (Journal of Ners and Midwifery), 1(3), pp.230-235.

2. Handayani, Dewi, et al. 2012. Perawatan Bayi Baru : Paduan Lengkap untuk lbu Merawat Bayi 0-6 Bulan. PT Aspirasai Muda, Jakarta.

3. Irmawati. 2015. Bayi dan Balita Sehat dan Cerdas. PT Elex Media Komputindo, Jakarta.

4. Riadiani, Lia. Analisis Pijat Bayi Dengan Kualitas Tidur Bayi Umur 6-12 bulan. 2010.

5. Roesli, Utami. 2010. Pedoman Pijat Bayi. Jakarta: PT. Trubus Agriwidya.

6. Siti Rohmah. 2016. Efektifitas Baby Spa Terhadap Lama Tidur Bayi Usia 3-4 Bulan di BPM Bidan Siti Fatimah Kota Cimahi Tahun 2016. Jurnal Bidan. Midwife Journal. Volume 2 No. 02, Juli 2016, pISSN 2477-3441. elSSN 2477-345X.

7. Sudarti. 2015. Hubungan Antara Pijat Bayi Dengan Kualitas Tidur Bayi Usia 612 Bulan Di Bpm Atika, A.Md.Keb. Kabupaten Madiun Tahun 2015. Akademi Kebidanan Madiun.

8. Syaukani, Aulia. 2015. Petunjuk Praktis Pijat Senam dan Yoga Sehat untuk Bayi. Araska, Yogyakarta.

9. Warsini, W. and Nugraini, D., 2016. Pengaruh pijat bayi terhadap lama tidur bayi di desa Duwet kecamatan Wonosari kabupaten Klaten. Jurnal IImu Kesehatan Kosala, 4(1).

10. Bintang Aji, Pamungkas. 2016. Pengaruh pijat bayi dengan kualitas tidur Bayi Usia 0-6 Bulan Di Puskesmas Kartasura . Fakultas IImu Kesehatan, Universitas Muhammadiyah Surakarta. 